\title{
Analisis Kegagalan Retak dan Teknologi Perbaikan Sudu Turbin Jenis Inconel 792 pada Pesawat Terbang
}

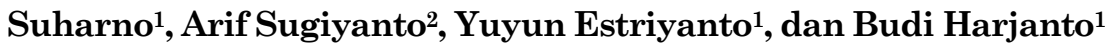 \\ 1 Universitas Sebelas Maret Surakarta \\ 2 PT.Garuda Maintenance Facilities Jakarta \\ E-mail: myharno@yahoo.com
}

\begin{abstract}
ABSTRAK
Penelitian untuk melakukan analisis terhadap kegagalan retak telah dilakukan pada sudu turbin dari Auxiliary Power Unit (APU) pesawat terbang. Bahan sudu turbin adalah paduan super Inconel 792. Pengujian yang dilakukan meliputi inspeksi visual, pengujian komposisi kimia, fractography, pengujian kekerasan, dan metalografi.Hasilnya menunjukkan bahwa patah dimulai dari celah dan retak makro dan kemudian menjalar/merambat menjadi retak terbuka di permukaan.Hal ini kemungkinan disebabkan oleh mekanisme retak panas selama perbaikan las sebelumnya. Kandungan Aluminium dan Titanium yang tinggi pada logam las, menjadikan material menjadi rapuh, hal ini ditunjukkan oleh fitur intergranular dibandingkan dengan aspek pembelahan transgranular menunjukkan bahwa keuletan pada lasan rendah. Dibandingkan dengan sudu yang tidak rusak (gagal), ukuran butir dari sudu turbin yang rusak adalah sangat berbeda menunjukkan eksposisi terhadap panas baik dari siklus termal pengelasan atau lingkungan operasi normal pada suhu tinggi.Teknik perbaikan lebih lanjut dikembangkan berdasarkan keberhasilan PQTR yang di uji dengan kekerasan mikro, destructive dan non destructive test.Untuk tujuan ini maka dipilih las GTAW yang diikuti dengan solution dan aging treatment.
\end{abstract}

Kata kunci: Paduan super, perbaikan pengelasan, fractography, metalografi, analisis kegagalan.

\begin{abstract}
The failure analysis has been performed on fractured blade of turbine wheel assembly of an Auxiliary Power Unit (APU). The turbine wheel is made of as-cast nickel-base superalloy Inconel 792. To support the analysis, laboratory ractices including visual inspection, photography, stereomicroscopy, chemical composition testing, fractography, hardness testing, and metallography were conducted. Thermo-mechanical fatigue, overheating, hot corrosion, and creep are beyond the conclusion of the failure mode. The evidence shows that the fracture maybe initiated from fissures and macrocracks and then propagated to become an open-surface crack. It may come from hot cracking mechanism during previous weld repair. In addition to high content of Aluminum and Titanium in weld metal, the brittleness shown by the intergranular features compared to the transgranular cleavage facets indicate that the weldment ductility is low. Compared to unfailed blade, grain size of the failed blade is markedly different showing exposition to heat either from welding thermal cycle or abnormal operating environment at elevated temperature. Further repair scheme is developed based on successful PQTR from microhardness, nondestructive, and destructive testing. Thus, GTA Welding followed by Solution and Aging Treatment is chosen.
\end{abstract}

Keywords: Superalloy, weld repair, fractography, metallography, failure analysis

\section{PENDAHULUAN}

Secara umum sebuah sudu turbin yang digunakan dalam unit penambah daya atau Auxiliary Power Unit (APU) pada pesawat terbang apabila telah bekerja selama 857 jam TSI (Waktu Sejak Terpasang), dilakukan penyelidikan untuk menge- tahui performa dari mesin tersebut [1]. Pemeriksaan terhadap APU dilakukan secara menyeluruh apabila ada indikasi suara yang tidak normal.Biasanya hasil pemeriksaan secara menyeluruh terhadap suara yang tidak normal tersebut dapat diketahui bahwa roda turbin ditemui aus, ada kerusakan, dan bahkan terjadi hingga ujung dari sudu hilang 
karena patah (cuil). Roda turbin pesawat terbang yang mengalami kegagalan kebanyakan terbuat dari bahan paduan super (superalloy) jenis Inconel 792 [1]. Menurut Pedoman Pemeliharaan Pesawat, kecepatan turbin nominal roda 41,000 rpm, kecepatan operasi biasanya 101,3\%-102,5\%, dan temperatur operasi antara $566^{\circ} \mathrm{C}-650^{\circ} \mathrm{C}[2]$.

Gambar 1 menunjukkan diagram skematik sistem kerja dari APU (pandangan atas) dan gambaran umum dari semua sudu turbin yang mengalami kegagalan dan sampling dari dua ujung roda turbin untuk dilakukan pemeriksaan metalurgi. Konstruksi APU terdiri dari dua bagian yaitu kompresor sentrifugal dan roda turbin yang berputar pada poros utama [3].

Tentu saja dalam kasus-kasus khas dari kegagalan, biasanya kerusakan bermula dari sudu/ pisau undeformed kemudian berdampak pada pisau-pisau yang berdekatan sehingga mengakibatkan cacat. Gambar 1 menunjukkan bukti dari kedua kegagalan pada pisau yaitu cacat pisau dan pisau undeformed. Jumlah undeformed dan deformed masing-masing adalah 5 bilah (25\%) dan 15 pisau (75\%). Dalam semua kasus, cacat gerigi pisau bersumber dari pisau undeformed sebagai dampak objek massal pada suhu operasi yang tinggi. Pisau bergerigi mengalami cacat plastis pada arah radial.

Atas dasar permasalah di atas maka dapat ditentukan sebuah hipotesis bahwa sudu turbin mengalami tegangan plastis-elastis yang berulangulang sebagai akibat dari pemanasan dan pendinginan selama periode start-up dan shut-down. Akibatnya, kelelahan siklus rendah merupakan pertimbangan penting [4]. Mengenai sifat pembebanan, suhu lingkungan, dan bahan Inconel 792, modus kegagalannya adalah kelelahan termo-mekanis, korosi panas, pecah creep, dan kegagalan over heating [5].

Tujuan dari penelitian ini adalah untuk mengetahui penyebab utama kegagalan retak sudu turbin pada pesawat terbang. Setelah diketahui penyebab kerusakan, maka data penyebab kerusakan tersebut akan dijadikan rekomendasi untuk melakukan rekayasa teknologi perbaikan pada sudu turbin yang mengalami kerusakan.

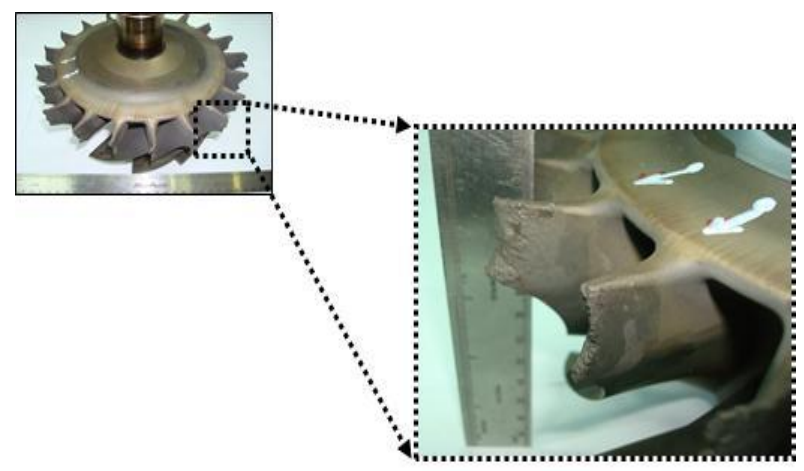

Gambar 1. Gagal dan Aus Ujung Sudu Roda Turbin karena Retak

\section{METODE PENELITIAN}

Bahan yang dipakai pada riset ini adalah sudu turbin wheel Auxiliary Power Unit yang dipakai oleh pesawat Garuda Indonesia Boeng 737 yaitu material superalloy jenis Inconel 792 berkode 3842360-1. Filler metal yang dipakai menggunakan jenis 5837 AMS (Inconel 625), pengelasan satu sisi, DCEN 30-35 polaritas A. Pengujian yang dilakukan meliputi uji komposisi kimia, metalografi, dan uji kekerasan.

Alat yang digunakan dalam penelitian ini adalah: Quantitative Metallography Tool, Model RAX Vision MM-10A from Rax Inc.milik, mesin gerinda dan poles, mesin SEM (Stereo Microscope) Model Olympus DP10 dengan lensa Olympus SZPT \& SZ60. Micro Hardness Tester model Shimadzu HMV-2 dan Macro Hardness Tester merk Mitutoyo AR-10. Sehubungan dengan bahan baku nickelbased superalloy sebagai bahan dasar Inconel 792 yang sulit untuk dapat dibeli maka spesimen uji tes akan dibuat langsung dari roda turbin yang memiliki 20 sudu. Jumlah specimen adalah 16 buah yang berbentuk plat (1.6mm X 20mm X 100mm). Specimen yang dibuat disiapkan dari sudu yang masih dalam kondisi baik, yang penyiapannya dengan menggunakan mesin EDM merk Sodik. Sambungan las mengacu pada stadar AWS D17.1 dan AWS B2.1. dan jenis pengelasan yang akan digunakan adalah pengelasan jenis Gas Tungsten Arc Welding (GTAW) dengan sambungan tumpul (lap joint). Sebelum melakukan uji destruktive dan non distructive, terlebih dahulu dilakukan uji visual dan metalografi untuk mengetahui geometri sambungan.

Karena retak panas sebagai faktor penyebab kerusakan pada blade seperti yang dijelaskan dalam referensi sebelumnya [4], maka siklus perlakuan panas akan dirancang sedemikian rupa sehingga mendapatkan penelitian yang terbaik untuk mengurangi kecenderungan retak panas. Ada tiga siklus perlakuan panas yang akan dirancang sebagai kombinasi dari pemanasan mula (preheat) yaitu Solution Treatment (ST), GTAW, dan PWHT (Post Weld Heat Treatment) dengan Solution Treatment dan Aging Treatment (ST+AT). Dengan demikian, siklus perlakuan akan dilaksanakan secara berturut-turut adalah ST + GTAW + ST + AT, GTAW + ST + AT, dan hanya GTAW. Rincian dari kedua siklus perlakuan panas pertama dan kedua ditampilkan dalam Gambar 3, sedangkan siklus ketiga tidak ditampilkan untuk kesederhanaan karena hanya GTAW. Solutions Treatment dilakukan di tungku vakum tinggi pada temperatur 1120 ${ }^{\circ} \mathrm{C}$ dengan waktu tahan (holding time) selama 4 jam kemudian diikuti dengan pendinginan kejut di dalam gas argon sampai dengan temperatur kamar. Sedangkan Aging Treatment dilakukan pada tempe- 
ratur pemanasan pertama $1080{ }^{\circ} \mathrm{C}$ dengan waktu tahan (holding time) selama 4 jam kemudian diikuti dengan pendinginan kejut (quenching) dengan gas argon. Untuk memperbaiki butir struktur mikronya maka dilakukan pemanasan kedua pada temperatur $845{ }^{\circ} \mathrm{C}$ dan waktu tahan 24 jam, kemudian diikuti dengan pendinginan udara.

\section{HASIL DAN PEMBAHASAN}

Uji komposisi kimia dimaksudkan untuk mengetahui kandungan unsur-unsur kimia yang terdapat di dalam sudu turbin. Hal ini perlu dilakukan agar dapat dipastikan bahwa material yang diuji adalah sudu turbin berbahan dasar nikel (inconel 792). Selain itu, dengan uji komposisi kimia dapat dilihat unsur kimia tertentu yang mungkin berpengaruh signifikan terhadap material. Hasil uji komposisi kimia disajikan pada Tabel 1. Berdasarkan Table 1, diketahui bahwa logam las (setelah dilakukan perbaikan dengan las sebelumnya) mengandung Aluminium (Al) dan Titanium (Ti) yang tinggi. Material dengan kandungan $\mathrm{Al}$ dan $\mathrm{Ti}$ yang tinggi memang terbukti rentan terhadap retak panas secara.Semakin tinggi kandungan keduanya, semakin rendah mampu lasnya [6].

Tabel 1. Komposisi Kimia Logam Induk dan Logam Las pada Inconel 792

\begin{tabular}{ccccc}
\hline & \multicolumn{4}{c}{ Sudu turbin inconel 792 } \\
\cline { 2 - 5 } No & \multicolumn{2}{c}{ Base Metal } & \multicolumn{2}{c}{ Weld Metal } \\
\cline { 2 - 5 } & $\begin{array}{c}\text { Unsur } \\
\text { Kimia }\end{array}$ & $\begin{array}{c}\text { Kandungan } \\
\text { (\%) berat }\end{array}$ & $\begin{array}{c}\text { Unsur } \\
\text { Kimia }\end{array}$ & $\begin{array}{c}\text { Kandungan } \\
\text { (\%) berat }\end{array}$ \\
\hline 1 & $\mathrm{C}$ & 0,2 & $\mathrm{C}$ & 2,23 \\
2 & $\mathrm{Ni}$ & 60 & $\mathrm{Ni}$ & 71,91 \\
3 & $\mathrm{Cr}$ & 13 & $\mathrm{Cr}$ & 15,23 \\
4 & $\mathrm{Co}$ & 9 & $\mathrm{Co}$ & - \\
5 & $\mathrm{Mo}$ & 2 & $\mathrm{Mo}$ & - \\
6 & $\mathrm{Fe}$ & - & $\mathrm{Fe}$ & 2,26 \\
7 & $\mathrm{Al}$ & 3,2 & $\mathrm{Al}$ & 2,59 \\
8 & $\mathrm{~B}$ & 0,02 & $\mathrm{~B}$ & - \\
9 & $\mathrm{Ti}$ & 4,2 & $\mathrm{Ti}$ & 3,28 \\
\hline
\end{tabular}

Gambar 3 memperlihatkan tampilan patah pada ujung permukaan arah radial. Gambar ter-

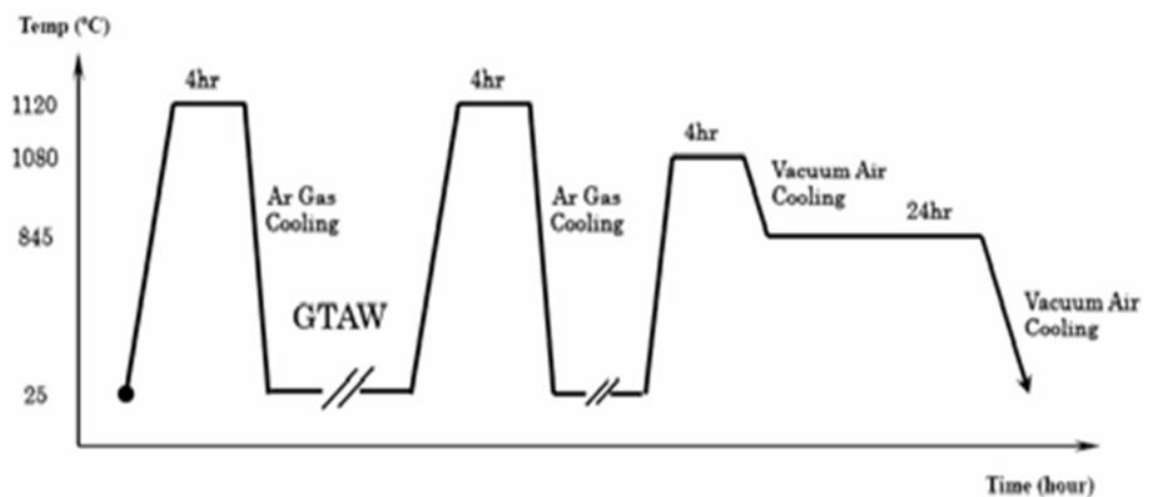

Treatment \#1 Heat treatment cycle by solution annealing. GTA Welding, and re-solution annealing and precipitation aging treatment for 3 ea test coupon

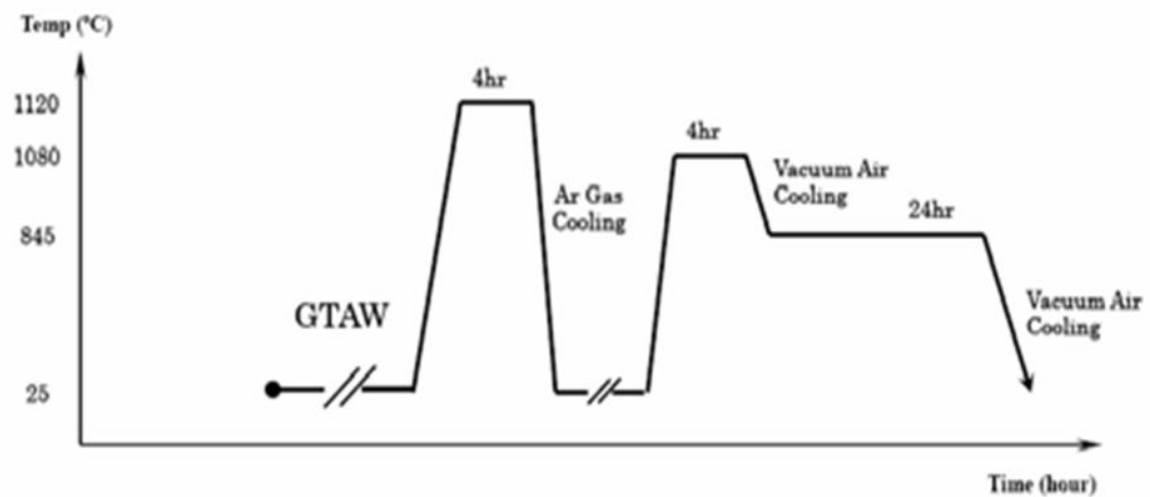

Treatment \#2 GTA Welding followed by heat treatment cycle by solution annealing and precipitation aging treatment for 3 ea test coupon

Gambar 2. Perlakuan Panas untuk Rekayasa Perbaikan Sudu Turbin 
sebut menunjukkan kondisi sudu yang telah retak, pecah, dan cacat plastis. Gambar sebelah kiri (LH) menunjukkan permukaan sudu dengan sedikit deformasi, sisi pusat (RKT) menunjukkan cacat permukaan dengan deformasi plastis, sedangkan $\mathrm{RH}$ adalah sisi sudu bagian ujung yang normal.Pada bagian LH dan RKT jelas menunjukkan retak kecil bercabang yang tajam di sepanjang bagian. Tampilan gambar pada $\mathrm{RH}$ menunjukkan retak jenis intergranular. Tidak ada indikasi gradasi nyata yang menunjukkan tanda kegagalan akibat kelelahan. Hal ini menguatkan bahwa material (bagian yang ditampilkan) merupakan material dengan kemampuan las yang rendah

Uji struktur mikro dilakukan pada sudu turbin C (Gambar 3). Uji ini bertujuan untuk mengetahui jenis dan geometri cacat (Gambar 4). Hasilnya menunjukkan bahwa terdapat satu retak besar (macrocrack) dan dua retak mikro (microcracks). Panjang retak yang terukur masing-masing adalah $3578 \mu \mathrm{m}, 1011 \mu \mathrm{m}, 574 \mu \mathrm{m}$. Dari Gambar 4 juga terlihat adanya perbedaan yang sangat jelas antara derah A dan B. Hal ini berarti antara daerah A dan daerah B ada perbedaan struktur mikro dan kemungkinan juga perbedaan komposisi kimia.

Berdasarkan Gambar 4, menunjukkan bahwa daerah antar A dan B merupakan Heat Affected Zone (HAZ). Pertemuan antara keduanya merupakan daerah garis fusi. Celah dan retakan diamati terutama di daerah garis fusi. Panas atau retak cair mungkin terjadi selama proses (fusi) pengelasan karena ukuran butir yang membesar. Retak cair sensitif terhadap jumlah dan lokasi yang menyebabkan terjadinya presipitasi fase kedua [6]. Bentuk ukuran butir jika dibandingkan dengan struktur mikro dendritik raw material dari sudu turbin memperlihatkan bentuk dendritik yang kasar dan tampak seperti tulang ikan (Gambar 5). Jenis ini biasanya disebut dengan denderitik tulang ikan.

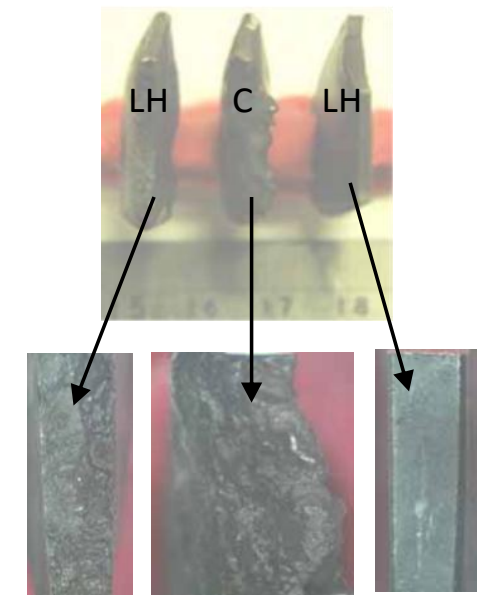

Gambar3. Struktur Makro Sudu Turbin. Ujung Sudu Sedikit Mengalami Deformasi (LH), ujung sudu yang rusak $(\mathrm{C})$, dan sudu turbin yang tidak rusak. (Pembesaran 10X).

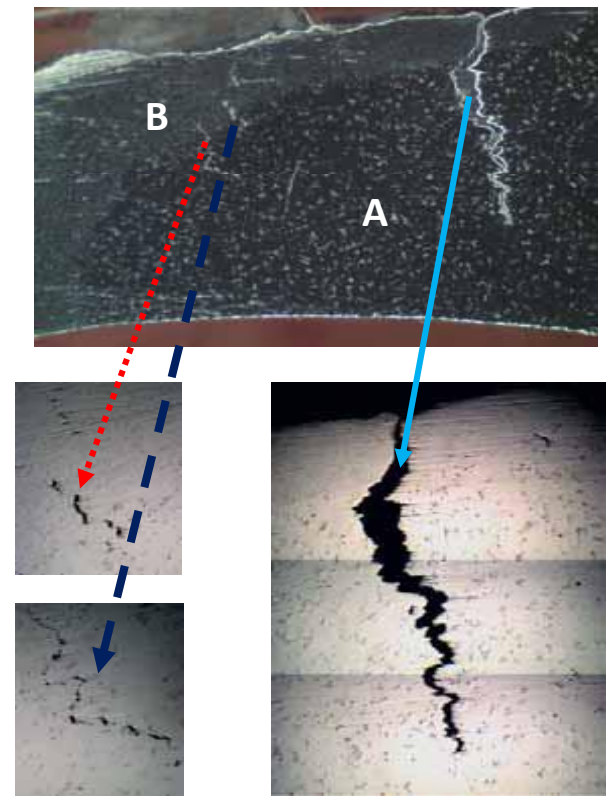

Gambar 4. Pembukaan Retak Makro, Garis Merah untuk LH, Garis Biru untuk RH

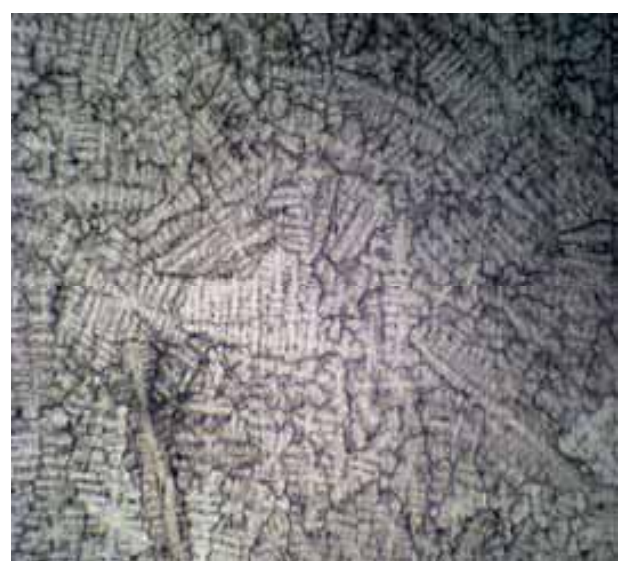

Gambar 5. Dendritik Kasar dan Strutur Tulang Ikan pada Sudu Turbin Unfailed (pembesaran 50X)
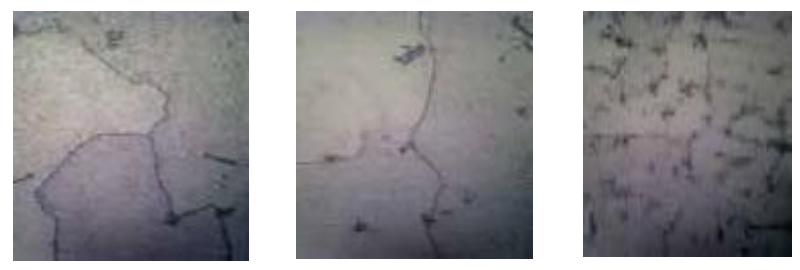

Gambar 6. Struktur Mikro dari the Undeformed (a), the Deformed (b), dan the Unfailed Blade (c), pembesaran 500X

Struktur mikro dari sudu yang tidak cacat adalah dendritik kasar atau denderitik tulang ikan (Gambar 5), sedangkan struktur mikro pada sudu turbin yang cacat terdiri dari butir equi-axed (Gambar 6). Denderitik tulang ikan adalah dendrit yang khas sebagai struktur cor di mana solidifikasi tidak terganggu oleh rekristalisasi. Sedangkan butir equi-axed atau kristal poligonal mengkarakterisasi sebuah struktur mikro yang mengalami rekristali- 
sasi. Bahan Inconel 792 memiliki susunan kristal gamma (Y') yang memiliki suhu cair antara 1100$1150{ }^{\circ} \mathrm{C}$ [6]. Dari Gambar 6 juga terlihat bahwa sudu yang cacat memiliki ukuran butir lebih besar dari pada sudu yang tidak cacat.

Gambar 7 menunjukkan satu set uji fractograph dengan SEM yang diambil dari sudu turbin yang cacat $(\mathrm{LH})$ dan sudu turbin yang tidak cacat (RH). Uji ini menggunakan SEM dengan pembesaran 1000X. Hasilnya menunjukkan bahwa tampilan retak pada LH adalah jenis intergranular sedangkan pada RH adalah transgranular. Tampilan gambar yang merupakan bagian dari proses pemgerjaan pemesinan dapat menyebabkan terjadinya deformasi plastik pada bagian bawah permukaan [7].

Patah arah melintang terjadi di semua ujung sudu turbin pada ketinggian rata-rata $108 \mathrm{~mm}$ jauh dari pusat sudu turbin yang memiliki diameter keseluruhan $219 \mathrm{~mm}$. Hal ini dapat dikatakan bahwa patah yang terjadi dihasilkan dari sudu yang berputar dan membentur yang berdekatan. Tegangan yang terjadi pada sudu itu terutama disebabkan oleh rotasi sentrifugal sudu. Fitur patah intergranular dibandingkan dengan aspek retak transgranular menunjukkan bahwa ketangguhan sudu undeformed (yang lebih tinggi kekerasan) lebih rendah dari pada ketangguhan sudu cacat (kekerasan lebih rendah).

Hasil pengamatan menunjukkan bahwa ada perbedaan ukuran butir antara sudu yang tidak cacat dan yang cacat, serta terlihat adanya kesesuaian antara butir dendritik pada sudu yang tidak cacat dengan sifat mekanik dari sudu turbin (Gambar 6 dan 7). Pada ujung sudu turbin terlihat adanya dua bagian yang berbeda, dan di prediksi merupakan daerah las dan logam induk.Munculnya daerah tersebut merupakan bukti bahwa ujung sudu turbin telah mengalami perbaikan dengan teknik pengelasan yang dilakukan sebelumnya.
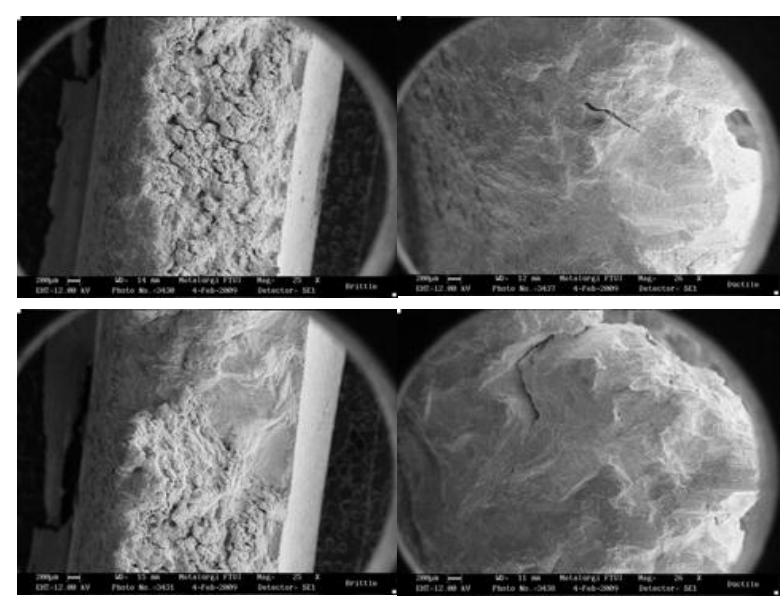

Gambar 7. Uji Fractografi pada Sudu Turbin untuk LH dan RH (Pembesaran1000X)
Retak makro dan cleavage diamati terdapat pada garis fusi atau HAZ (Gambar 5). Cacat las ini mungkin terjadi disebabkan oleh adanya retak panas selama proses pembekuan pasca pengelasn. Dari analisis terhadap struktur mikro yang ada dapat diperoleh bukti yang menunjukkan bahwa kekuatan sambungan las yang dilakukan sebelumnya adalah rendah.

Karena retak makro dan mikro (fisure) ditemukan selama pemeriksaan metalografi, maka hal yang harus diperhatikan untuk melakukan pengelasan superalloy adalah bahwa retak atau microfissuring mungkin terjadi di bawah permukaan dan tidak terdeteksi oleh uji dengan metode cairan penetran, selanjutnya fisur dan microcrack mungkin akan dapat terdeteksi dengan menggunakan x-ray.

Berdasarkan analisis struktur mikro dan karakteristik kerusakan yang terjadi pada bahan sudu turbin inconel 729, maka pengembangan terhadap teknik perbaikan sudu turbin yang rusak dapat dilakukan. Pengembangan perbaikan difokuskan pada upaya melakukan perbaikan dengan teknik las yang tepat dengan diikuti perlakuan panas pasca pengelasan dengan tepat pula. Pada pengembangan perbaikan ini pengelasan menggunakan jenis GTAW yang disertai dengan satu set teknik perlakuan panas, Gambar 2.

Struktur mikro hasil pengembangan teknologi perbaikan pada sudu turbin inconel 729 adalah sebagaiman terlihat pada Gambar 8.

Uji kekerasan dilakukan setelah karakteristik material dan jenis kegagalan retak telah diketahui. Tujuan dari pengujian ini adalah untuk mengetahui distribusi kekerasan pada ujung sudu turbin setelah dilakukan perbaikan dengan pengelasan. Hal ini diarahkan agar dapat dibuat sebuah rancangan saran (rekomendasi) untuk melakukan perbaikan dengan pengelasan pada tahap selanjutnya. Hasilnya menunjukkan bahwa ada perbedaan yang cukup signifikan antara kekerasan pada material yang di beri PWHT dan yang non PWHT. Angka kekerasan yang diperoleh adalah berkisar antara kisaran 330-440 HVN. Dari angka kekerasan yang diperoleh terlihat bahwa kekerasan relatif pisau yang cacat lebih lunak dari dua yang lain.

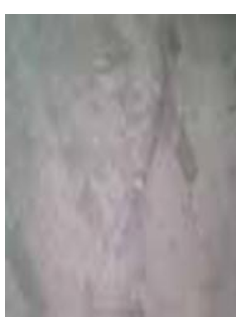

a

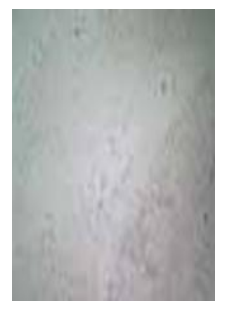

b

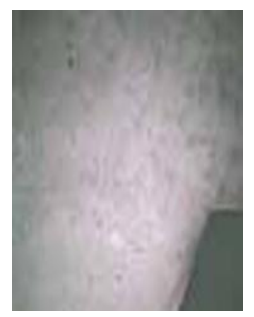

c
Gambar 8. Perbedaan Struktur Mikro pasca PWHT, a. Daerah las, b.Daerah fusion line, dan c Daerah HAZ 


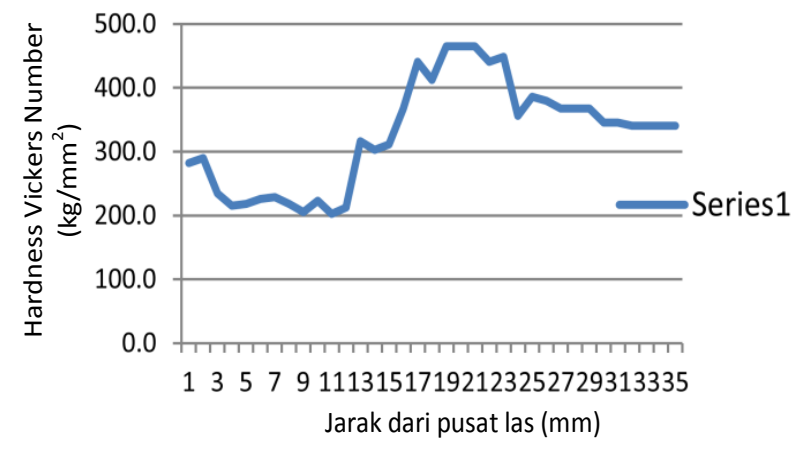

(a)

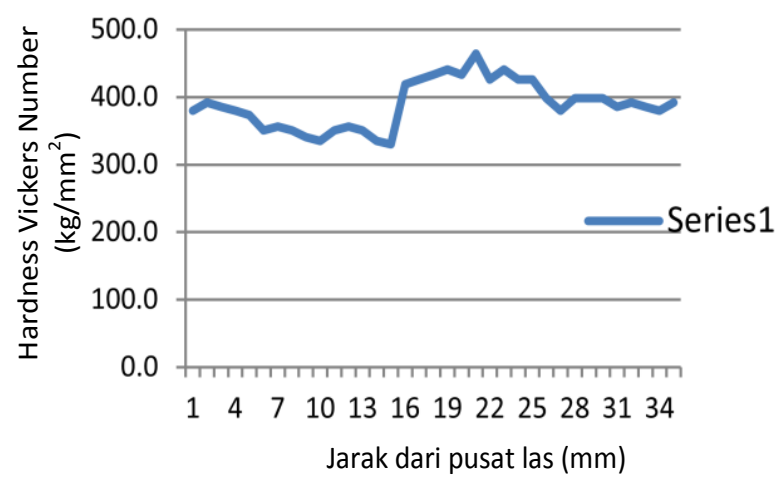

(b)

Gambar 9. Kekerasan pada Perbaikan dengan Las, a. non PWHT, b. dengan PWHT

Berdasarkan pengamatan struktur mikro dan kekerasan terlihat bahwa PWHT berhasil menyeragamkan butir Kristal (Gambar 8) sehingga kekerasannya lebih merata (Gambar 9), dengan demikian proses perbaikan dengan teknik las hasil pengembangan dapat diterapkan pada perbaikan sudu turbin pesawat terbang.

\section{KESIMPULAN}

Berdasarkan hasil penelitian dan pembahasan terhadap analisis kegagalan dan studi pengembangan perbaikan maka dapat diambil kesimpulan bahwa bahan dari sudu turbin yang dianalisis adalah termasuk jenis Inconel 792, yaitu bahan paduan super berbasis nikel.
Struktur mikro raw material dari bahan sudu turbin adalah dendritik atau tulang ikan. Peristiwa patah melintang yang terjadi pada daerah ujung desebabkan oleh fraktur seketika. Hal ini disebabkan oleh adanya benturan dari sudu undeformed ke arah sudu berdekatan yang menyebabkan kerusakkan roda turbin. Penampilan fitur intergranular dibandingkan dengan aspek retak transgranular menunjukkan perbedaan ketangguhan dan keuletan antara sudu undeformed dan sudu cacat. Retak makro dan retak celah pada daerah fusion line dan HAZ disebabkan oleh adanya retak panas pada saat peristiwa pengelasan. Mengingat inconel 792 mengandung $\mathrm{Al}$ dan Ti yang ringgi, sementara unsur tersebut mengurangi kemampuan las, maka elektroda las dapat dipilih jenis inconel 625 yang memiliki Al dan Ti yang lebih rendah. Hasil siklus perlakuan panas (PWHT) terbukti dapat digunakan sabagai acuan dasar untuk teknik perbaikan pada sudu turbin yang mengalami kegagalan. Hal ini terlhat dengan adanya pemerataan kekerasan mikro sepanjang logam las, HAZ, dan logam dasar.

\section{DAFTAR PUSTAKA}

[1] Unknown, Inspection Repair Manual (IRM), Honeywell Inc, Phoenix AZ, ATA 49-21-73, 603, 2007.

[2] Unknown, Maintenance Manual (MM), Seattle: Boeing Co, ATA 49-41-00, 1-5, ATA 49-00-00, 102, ATA 49-11-00, 207-213, 2008.

[3] Unknown, Maintenance Manual (MM), Phoenix: Honeywell Inc, ATA 49-20-00, 1-10, 2003.

[4] Petrenec M., Obrtlík K., Polák J., and Man J., Effect of Temperature on the Low Cycle Fatigue of Cast Inconel 792-5A, Key Eng Mater, Vols. 345-346: 383-386, 2007.

[5] Donachie M.J. and Donachie S.J. Superalloys: $A$ Technical Guide, 2nd Edition, Materials Park OH: ASM Intl, 150-337, 2002.

[6] Carter T.J., Common Failures in Gas Turbine Blades. Eng Fail Anal, Vol. 12: 237-247, 2005.

[7] Bhusan B., Principles and Application of Tribology, Toronto: John Wiley and Sons, 496509, 1999. 